\title{
Allan Patten, Equal Recognition. The Moral Foundations of Minority Rights
}

\author{
Erik De Bom
}

\section{Alan Patten, Equal Recognition. The Moral Foundations of Minority Rights (Princeton - Oxford: Princeton University Press, 2014)}

De meest succesvolle en invloedrijke theorie over minderheidsrechten is tot op vandaag die van Will Kymlicka. De basis daarvoor legde hij in de jaren negentig van de vorige eeuw. Hoewel de theorie vaak onder vuur is genomen vanuit verschillende hoeken, blijft ze tot op vandaag in grote mate overeind. Ook Equal Recognition verandert daar eigenlijk niets aan, al is het wel zo dat Alan Patten met dit boek de meest gesofisticeerde filosofische verdediging biedt van minderheidsrechten vanuit een liberaal cultureel standpunt sinds de eerste publicaties daarover door Kymlicka. De studie van Patten is een 'herformulering van de ethische basisprincipes van liberaal culturalisme' (p. 5).

Als liberaal politiek filosoof hecht Patten in de eerste plaats belang aan het individu en diens opvattingen over het goede leven. Het is de taak van gelijk welke liberale staat om die verschillende opvattingen te respecteren, en dus moet de staat neutraal zijn tegenover de levenskeuzes die individuen maken. Dit impliceert niet dat een staat geen belang hecht aan cultuur of zichzelf los ziet van cultuur, maar dat ze elke cultuur op een gelijke manier erkent. Gezien dat grote belang van cultuur staat de auteur in de eerste twee hoofdstukken stil bij (1) wat we precies onder cultuur dienen te verstaan en (2) waarom cultuur zo belangrijk is dat het ook binnen de liberale politieke filosofie een niet te verwaarlozen onderwerp is. Pattens concept van cultuur onderscheidt zich van essentialistische opvattingen die al te zeer uitgaan van heldere, afgebakende en homogene voorstellingen van cultuur. Hij ziet cultuur veeleer als een soort neerslag. Mensen delen een cultuur als en in de mate dat ze onderworpen zijn aan een aantal vormgevende voorwaarden die verschillen van de voorwaarden waaraan anderen onderworpen zijn. Die voorwaarden zijn constituerend voor een gedeelde cultuur. In zijn zoektocht naar het belang van cultuur vertrekt Patten vanuit een negatieve stellingname: welke nadelen zouden mensen ondervinden indien het voortbestaan of de beleving van hun cultuur in het gedrang komt? Belangrijk voor zijn uiteenzetting is dat het gaat om nadelen die van een dergelijke aard zijn dat ze leiden tot een rechtsclaim. De reden dat cultuur zo belangrijk is, is dat cultuur een keuzecontext biedt. Mensen van wie de cultuur verdwijnt, ondervinden mogelijk dergelijk nadeel omdat hun keuzecontext serieus wordt ingeperkt.

Het interessante aan Pattens theorie is dat hij niet automatisch pleit voor het in stand houden van culturen. Voor hem is het in de eerste plaats belangrijk dat alle burgers een faire mogelijkheid tot zelfbepaling hebben. Dat wil zeggen dat faire 
achtergrondvoorwaarden tellen, zodat burgers die waarde hechten aan het voortbestaan of het succes van een specifieke cultuur kunnen streven naar het tot stand brengen van die uitkomst. Daarvoor zijn rechten nodig, maar geen rechten die een specifieke culturele uitkomst beogen, of rechten die ten volle inzetten op gelijke accommodatie of gelijke erkenning. De staat houdt zijn handen dus niet af van cultuur, maar erkent de culturele affiliaties van zijn burgers. Het idee van een faire mogelijkheid tot zelfbepaling verwacht niet van de staat dat die een bepaalde cultuur promoot, maar dat hij neutraal handelt ten overstaan van cultuur of culturen. Dat brengt Patten bij de kern van zijn theorie, die hij ontwikkelt in de hoofdstukken 4 en 5 .

Het eerste deel van die theorie berust op een eigen interpretatie van 'neutraliteit' voor. Zowel neutraliteit van rechtvaardiging als neutraliteit van effecten wijst hij af. Onder het eerste verstaat hij een beleid dat voor zijn rechtvaardiging geen beroep doet op de superioriteit van bepaalde opvattingen over het goede en niet gebruikmaakt van de verschillen in opvattingen over het goede. Met de tweede vorm van neutraliteit bedoelt hij elk beleid dat - rekening houdend met een gepaste ondergrens - geen effect heeft op het al dan niet meer of minder succesvol maken van een bepaalde opvatting van het goede zonder ook niet meteen maatregelen te nemen om rivaliserende opvattingen over het goede in dezelfde mate meer of minder succesvol te maken. Wat Patten voorstelt, is neutraliteit van behandeling, en dat is elk beleid dat niet meer of minder ten dienste staat van bepaalde opvattingen van het goede dan tegenover andere opvattingen. In deze interpretatie draait het in eerste instantie dus niet om de uitkomst van het beleid of de intenties van de staat, maar om de input. De staat dient op een gelijke manier verschillende opvattingen van het goede te ondersteunen of te belemmeren door bijvoorbeeld twee goederen op eenzelfde manier te subsidiëren of belasten, waarvan het ene gebruikt wordt voor een opvatting van het goede en het andere voor een andere opvatting van het goede.

De zeer gedetailleerde uiteenzetting over neutraliteit vormt de basis voor Pattens theorie over culturele rechtvaardigheid. Maar daarmee is de kous niet af. Want wat betekent 'neutraliteit van behandeling' nu voor de rechtvaardiging van culturele rechten voor minderheidsgroepen? In deze context gaat hij uitvoerig in op het tweede deel van zijn theorie, dat volledig gewijd is aan 'gelijke erkenning' (de hoofdtitel van het boek). Erkenning in Pattens theorie is een vorm van accommodatie die door de staat wordt toegekend aan bepaalde opvattingen van het goede op voorwaarde dat die accommodatie niet algemeen van aard is maar toegesneden is op specifieke aspecten van die opvatting van het goede, en dat het voorwerp van erkenning direct betrekking heeft op de identiteit van de betrokken individuen. De aandacht voor gelijke erkenning is volgens de auteur meer dan gerechtvaardigd, omdat beschikken over de liberale basisrechten en -aanspraken geen voldoende voorwaarde is voor het al dan niet voortbestaan van culturen. Rechtvaardigheid vereist meer dan dat - Patten spreekt over 'basic liberal proceduralism' - omdat de staat in deze vooronderstelling geen waarde hecht aan de verschillende opvattingen van het goede van zijn burgers. Om dat te doen is in het 
licht van 'neutraliteit van behandeling' een 'gelijke erkenning' noodzakelijk. Daarmee heeft hij de twee pijlers van zijn theorie, van zijn rechtvaardiging van culturele rechten voor minderheden, tot in detail uitgewerkt.

In de drie resterende hoofdstukken laat Patten zien hoe zijn theorie 'werkt' wanneer ze wordt 'toegepast' op enkele concrete voorbeelden. 'Werkt' en 'toegepast' zijn enigszins misleidend, want de uiteenzetting is zeker niet minder theoretisch dan in de voorgaande hoofdstukken. Het gaat om domeinen waarin de staat vaak een vorm van erkenning toekent aan bepaalde opvattingen van het goede. Het eerste domein is dat van de taal of talen die door de staat worden erkend voor de werking van de publieke instellingen (niet alleen voor de interne communicatie of de communicatie naar de burgers toe, maar ook bijvoorbeeld voor door de staat gesubsidieerde scholen, en bij de rechtspraak). Het tweede domein is dat van de manier waarop de staat zich intern organiseert en al dan niet kiest voor een unitaire of federale structuur. In dat laatste geval moeten burgers onder meer uitmaken hoe en waar de grenzen van de federale delen worden getrokken, welke competenties bij welk niveau worden ondergebracht en op welke manier mogelijke conflicten tussen die niveaus worden beslecht. Indien een multinationale staat er niet in slaagt om gelijke erkenning toe te kennen aan de samenstellende delen, kan deze tekortkoming leiden tot een gerechtvaardigde eis tot afscheiding. Het laatste hoofdstuk is niet echt gewijd aan een specifiek domein, maar behandelt een zeer pertinente vraag, namelijk waarom zo vaak - ook binnen de politieke filosofie - een onderscheid wordt gemaakt tussen nationale groepen en gemeenschappen van immigranten.

$\mathrm{Na}$ het lezen van Equal Recognition kan de lezer niet anders dan besluiten dat Alan Patten een ongelooflijke tour de force heeft geleverd. Dit is politieke filosofie van de bovenste plank. Concepten worden haarfijn geanalyseerd, interpretaties tot in detail tegen elkaar afgewogen, en argumenten zeer zorgvuldig opgebouwd met uitermate veel oog voor elke mogelijke nuance. Een kritiek formuleren op wat zeker en vast kan worden aangeduid als de meest up-to-date en gesofisticeerde morele verdediging van minderheidsrechten op basis van de principes van neutraliteit van behandeling en gelijke erkenning is allerminst eenvoudig. Haast onvermijdelijk zal de kritiek zich moeten toespitsen op een specifiek deelaspect. Toch zou ik één algemene bedenking willen formuleren. Patten spreekt vaak over beleid. Dat brengt ons automatisch bij de vraag in welke mate dit boek dienstbaar zou kunnen zijn voor de ontwikkeling van beleid in heel concrete gevallen. Bijvoorbeeld: kan de theorie van Patten een mogelijke uitweg bieden - of ten minste een aanbeveling doen - voor de communautaire kwestie in België, die betrekking heeft op taalrechten, de vraag om afscheiding, en het al dan niet gerechtvaardigde onderscheid tussen autochtone en allochtone minderheidsgroepen (ik denk heel concreet aan de situatie in Brussel). Door de vele kwalificaties die Patten zelf in de loop van zijn uiteenzetting aanbrengt, wordt al snel duidelijk dat het allerminst evident is om zijn basistheorie over neutraliteit van behandeling en gelijke erkenning in de praktijk te brengen, en dat ze dus de beleidsmaker niet veel verder zal brengen. Maar het was niet zonder reden dat ik sprak over 'bedenking' in plaats 
van 'kritiek', omdat Pattens boek in de eerste plaats natuurlijk een morele fundering wil bieden en geen handboek voor constitutionalisten is. 